\title{
Classification of 'Sarraceniospora aurea' Furihata et al. 1989 as Actinocorallia aurea sp. nov.
}

\author{
Tomohiko Tamura, Kazunori Hatano and Ken-ichiro Suzuki \\ NITE Biological Resource Center (NBRC), National Institute of Technology and Evaluation, \\ 2-5-8 Kazusakamatari, Kisarazu, Chiba 292-0818, Japan
}

Correspondence

Tomohiko Tamura

tamura-tomohiko@nite.go.jp
The genus Actinocorallia, with a single species Actinocorallia herbida, was proposed by Iinuma et al. (1994). Subsequently, Zhang et al. (2001) enlarged the monotypic genus by reclassifying four species of the genus Actinomadura and emending the genus description. At the time of writing, the genus comprises six species with validly published names, including the recently described species Actinocorallia cavernae (Lee, 2006).

During a taxonomic study of strains assigned to genera with non-validly published names, it was revealed that two strains, NBRC 14752 and NBRC 15120, described as 'Sarraceniospora aurea' (Furihata et al., 1989) formed a phylogenetic cluster with the members of the genus Actinocorallia. In this paper, we describe the results of polyphasic taxonomic studies of the two strains and propose to assign them to a novel species of the genus Actinocorallia.

PCR-amplification and sequencing of the 16S rRNA gene and phylogenetic analysis were performed as described previously (Tamura \& Hatano, 2001). Strains NBRC 14752 and NBRC 15120 had identical 16S rRNA gene sequences and formed a monophyletic cluster with members of the genus Actinocorallia (Fig. 1). 16S rRNA gene sequence similarity calculations after a neighbour-joining analysis

Abbreviation: ISP, International Streptomyces Project.

The GenBank/EMBL/DDBJ accession number for the 16S rRNA gene sequences of Actinocorallia aurea sp. nov. NBRC $14752^{\top}$ and strain NBRC 15120 are AB006177 and AB006160, respectively.

A table detailing the cellular fatty acid contents of Actinocorallia aurea sp. nov. NBRC $14752^{\top}$ and selected members of the genus Actinocorallia, and a scanning electron micrograph of cells of the strain are available with the online version of this paper. indicated that the closest relatives of both strains were Actinocorallia herbida ( $98.9 \%$ gene sequence similarity), Actinocorallia aurantiaca (98.6\%), Actinocorallia glomerata (98.3\%), Actinocorallia longicatena $(98.1 \%)$ and Actinocorallia libanotica $(98.1 \%)$. Lower sequence similarities were found with Actinocorallia cavernae (97.3\%).

Analyses of whole-cell sugar patterns, cell-wall amino acids, menaquinones, cellular fatty acids, the acyl type of the peptidoglycan, mycolic acids and DNA G + C content were performed as described previously (Tamura et al., 1994). Freeze-dried cells for chemotaxonomic analyses were obtained from a culture grown in yeast extract-glucose broth $(1.0 \%$ yeast extract; $1.0 \%$ D-glucose; $\mathrm{pH} 7.0)$ on a rotary shaker at $28{ }^{\circ} \mathrm{C}$. The major menaquinones were MK$9\left(\mathrm{H}_{4}\right)$, MK-9 $\left(\mathrm{H}_{6}\right)$ and MK-9 $\left(\mathrm{H}_{8}\right)$ and a small amount of MK- $9\left(\mathrm{H}_{2}\right)$ was also present. The organisms have mesodiaminopimelic acid (meso-DAP), glutamic acid and alanine as cell-wall amino acids and glucose, galactose and small amounts of madurose and xylose as the wholecell sugars (wall chemotype/sugar pattern III/B sensu Lechevalier \& Lechevalier, 1970). The data differed from those reported by Furihata et al. (1989), in which the presence of arabinose and a trace of glycine were revealed and the cell-wall chemotype was designated as II/D. The diagnostic phospholipids phosphatidylethanolamine and phosphatidylglycerol were detected in strains NBRC 14752 and NBRC 15120, but phosphatidylcholine and some other phospholipids, including glucosamine, were not detected (phospholipid type PII sensu Lechevalier et al., 1977). The DNA G + C contents of strains NBRC 14752 and NBRC 15120 were 71.6 and $72.2 \mathrm{~mol} \%$, respectively. Mycolic acids were not detected. The acyl type of the muramic acid was acetyl. The fatty acid profile of strains NBRC 14752 


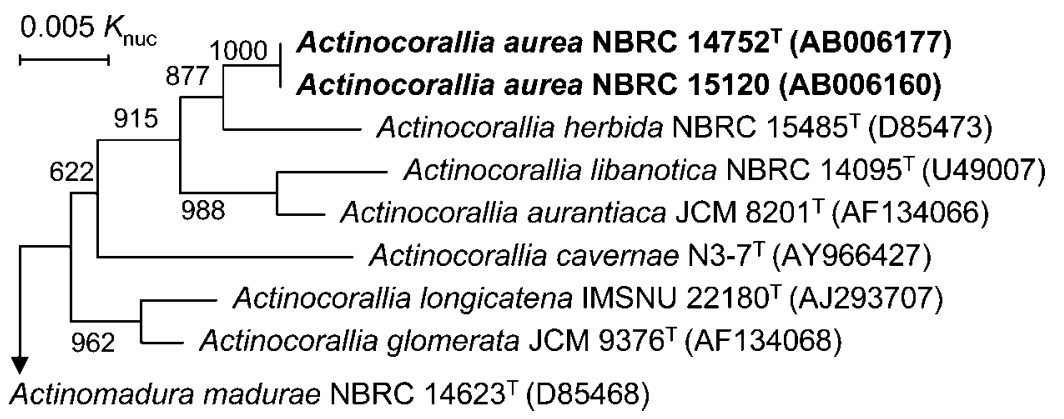

Fig. 1. Phylogenetic tree derived from $16 \mathrm{~S}$ rRNA gene sequences of strains NBRC $14752^{\top}$ and NBRC 15120 and species of the genus Actinocorallia. The tree was constructed by using the neighbour-joining method (Saitou \& Nei, 1987). The numbers on the branches are confidence limits (expressed as percentages) estimated from a bootstrap analysis with 1000 replicates. Bar, $0.005 K_{\text {nuc }}$ in nucleotide sequences. and NBRC 15120 (see Supplementary Table S1 in IJSEM Online) contained $\mathrm{C}_{16: 0}(21 \%$ and $22 \%$, respectively), $\mathrm{C}_{18: 1}(19 \%$ and $18 \%), 10$-methyl $\mathrm{C}_{18: 0}(10 \%$ and $14 \%)$, $\mathrm{C}_{17: 1}(13 \%$ and $9 \%), \mathrm{C}_{16: 1}(8 \%$ and $12 \%), 10$-methyl $\mathrm{C}_{16: 0}(4 \%$ and $10 \%), 10$-methyl $\mathrm{C}_{17: 0}(7 \%$ and $5 \%)$ and iso- $\mathrm{C}_{16: 0}(6 \%$ and $5 \%)$ (fatty acid type $3 \mathrm{a}$ sensu Kroppenstedt, 1985). No significant differences in the fatty acid profiles were found between strains NBRC 14752 and NBRC 15120 and A. herbida.
Morphological characteristics were observed by using scanning electron microscopy as described previously (Tamura et al., 2000). Strains NBRC 14752 and NBRC 15120 formed a straight to flexuous spore chain on the tip of coralloid sporophore as seen in A. herbida (Iinuma et al., 1994). A structure of the sheath, similar in shape to a North American pitcher plant of the genus Sarracenia, was occasionally observed at the tip of the spore chains as previously reported by Furihata et al. (1989) (see

Table 1. Differential characteristics of strains NBRC $14752^{\top}$, NBRC 15120 and type strains of closely related species of the genus Actinocorallia

Strains: 1, A. aurea sp. nov. NBRC $14752^{\mathrm{T}}$ and strain NBRC 15120; 2, A. herbida (data from this study); 3, A. aurantiaca; 4, A. libanotica [data from Goodfellow (1989), Trujillo \& Goodfellow (2003) and this study]. +, Positive; -, negative; ND, no data. The colour codes in parentheses correspond to the colour codes in A Mycological Colour Chart (Rayner, 1970). All strains utilize D-glucose, L-rhamnose and D-xylose but not Dfructose, myo-inositol, lactose, D-mannitol, glycerol, D-mannose, melibiose, raffinose or D-sorbitol.

\begin{tabular}{|c|c|c|c|c|}
\hline Characteristic & 1 & 2 & 3 & 4 \\
\hline \multicolumn{5}{|l|}{ Culture } \\
\hline \multicolumn{5}{|l|}{ Yeast extract-starch agar: } \\
\hline Aerial spore mass & Pale greenish yellow (46) & Pale greenish yellow (46) & White & White \\
\hline \multicolumn{5}{|l|}{ Maltose-Bennett's agar: } \\
\hline Aerial spore mass & Pale greenish yellow (46) & None & White & White \\
\hline \multicolumn{5}{|c|}{$1 / 4$ Yeast extract-malt extract agar: } \\
\hline Vegetative mycelium & $\begin{array}{c}\text { Moderate yellow (64) } \\
\text { to pale yellow ( } 45)\end{array}$ & $\begin{array}{l}\text { Moderate to strong } \\
\text { yellow }(47)\end{array}$ & $\begin{array}{l}\text { Colourless to light } \\
\text { yellow (11) }\end{array}$ & Moderate yellow (64) \\
\hline Aerial spore mass & Pale greenish yellow (46) & Pale greenish yellow (46) & White to pinkish white & White \\
\hline \multicolumn{5}{|l|}{ Physiological } \\
\hline Liquefaction of gelatin & + & - & + & + \\
\hline Hydrolysis of starch & + & + & - & + \\
\hline \multicolumn{5}{|l|}{ Utilization of: } \\
\hline L-Arabinose & + & + & - & + \\
\hline Maltose & + & + & - & + \\
\hline Sucrose & - & - & - & + \\
\hline Growth at $37^{\circ} \mathrm{C}$ & + & - & - & ND \\
\hline
\end{tabular}


Supplementary Fig. S1 in IJSEM Online). The tip of the sheath was similar in appearance to the operculum of a pitcher plant and the spore chain resembled the pitcher tube.

Determination of the cultural and physiological characteristics was performed as described previously (Gordon et al., 1974; Seino et al., 1985; Shirling \& Gottlieb, 1966; Yokota et al., 1993). Detailed results are provided in the species description and in Table 1. The colour of the aerial spore mass of strains NBRC 14752 and NBRC 15120 was nearly identical to that of $A$. herbida, but the colour of the vegetative mycelium was different. The two strains did not produce a soluble pigment on tyrosine agar (ISP medium 7). Gelatin liquefaction and growth were observed at $37{ }^{\circ} \mathrm{C}$ (Table 1).

The microplate-hybridization method developed by Ezaki et al. $(1988,1989)$ was applied to determine DNA-DNA relatedness. The DNA-DNA relatedness of strain NBRC 14752 with strain NBRC 15120 was 60 and $67 \%$ (reciprocal values), $27 \%$ and $34 \%$ with $A$. herbida NBRC $15485^{\mathrm{T}}$, and less than $18 \%$ with $A$. aurantiaca NBRC $16147^{\mathrm{T}}$, A. glomerata NBRC $15960^{\mathrm{T}}$ and A. longicatena NBRC $15961^{T}$. The two strains are distinguishable from the other members of the genus Actinocorallia by several phenotypic properties as shown in Table 1. Therefore, on the basis of morphological, physiological and chemotaxonomic data, DNA-DNA hybridization and phylogenetic distinctiveness, 'Sarraceniospora aurea' NBRC 14752 and strain NBRC 15120 should be placed in the genus Actinocorallia as members of a novel species, for which the name Actinocorallia aurea sp. nov. is proposed.

\section{Description of Actinocorallia aurea sp. nov.}

Actinocorallia aurea (au're.a. L. fem. adj. aurea golden).

The description is based on the data obtained in this study and also reported by Furihata et al. (1989). Aerobic, Grampositive, non-acid-fast actinomycete that produces branching, non-fragmented vegetative hyphae. Straight to flexuous chains of aerial spores are formed on the tip of coralloid sporophores. Spores are short, non-motile rods (0.6$0.9 \times 1.0-1.5 \mu \mathrm{m})$. Vegetative mycelium is yellow on maltose-Bennett's agar, yeast extract-malt-extract agar (ISP medium 2), inorganic salts-starch agar (ISP medium 4), glycerol-asparagine agar (ISP medium 5) and peptone-yeast extract-iron agar (ISP medium 6) and greyish white on oatmeal (ISP medium 3) and tyrosine agars (ISP medium 7). The aerial spore mass is yellow on yeast extract-starch agar, maltose-Bennett's agar, 1/4 strength ISP medium 2 and ISP medium 3. Tests for starch hydrolysis, nitrate reduction and gelatin liquefaction are positive. Does not produce a soluble pigment on ISP medium 7. Starch is weakly hydrolysed. Calcium malate is not dissolved. Tests for the coagulation and peptonization of milk give negative results. Optimum temperature for growth is $20-30{ }^{\circ} \mathrm{C}$. Grows at $37^{\circ} \mathrm{C}$, but does not grow at $45{ }^{\circ} \mathrm{C}$. Does not grow on $4 \% \mathrm{NaCl}$. DGlucose, L-rhamnose, D-xylose and maltose are utilized. The cell-wall peptidoglycan contains meso-DAP as the diagnostic diamino acid and the whole-cell sugars contain madurose as the diagnostic sugar, indicating that the cell-wall chemotype is III/B. The major fatty acids are $\mathrm{C}_{16: 0}, \mathrm{C}_{18: 1}, 10$-methyl $\mathrm{C}_{18: 0}$ and $\mathrm{C}_{17: 1}$. The major menaquinones are MK-9 $\left(\mathrm{H}_{4}\right)$, MK-9 $\left(\mathrm{H}_{6}\right)$ and MK-9 $\left(\mathrm{H}_{8}\right)$. The major polar lipids are phosphatidylglycerol and phosphatidylethanolamine. The DNA G $+\mathrm{C}$ content is $71-73 \mathrm{~mol} \%$ (determined by HPLC).

The type strain, NBRC $14752^{\mathrm{T}}\left(=\mathrm{DSM} 44434^{\mathrm{T}}\right)$, was isolated from soil.

\section{References}

Ezaki, T., Hashimoto, Y., Takeuchi, N., Yamamoto, H., Liu, S.-L., Miura, H., Matsui, K. \& Yabuuchi, E. (1988). Simple genetic identification method of viridans group streptococci by colorimetric dot hybridization and quantitative fluorometric hybridization in microdilution wells. J Clin Microbiol 26, 1708-1713.

Ezaki, T., Hashimoto, Y. \& Yabuuchi, E. (1989). Fluorometric deoxyribonucleic acid-deoxyribonucleic acid hybridization in microdilution wells as an alternative to membrane filter hybridization in which radioisotopes are used to determine genetic relatedness among bacterial strains. Int J Syst Bacteriol 39, 224-229.

Furihata, K., Ikeda, K., Shimazu, A. \& Seto, H. (1989). Sarraceniospora, a new genus of the Actinomycetales. In Actinomycetologica Forum 1989 Trends in Actinomycetology in Japan, pp. 9-12. Edited by Y. Koyama. Japan: The Society for Actinomycetes.

Goodfellow, M. (1989). Section 30 Maduromycetes. In Bergey's Manual of Systematic Bacteriology vol. 4, pp. 2509-2551. Edited by S. T. Williams. Baltimore: Williams \& Wilkins.

Gordon, R. E., Barnett, D. A., Handerhan, J. E. \& Pang, C. H. (1974). Nocardia coeliaca, Nocardia autotrophica, and the nocardin strain. Int J Syst Bacteriol 24, 54-63.

linuma, S., Yokota, A., Hasegawa, T. \& Kanamaru, T. (1994). Actinocorallia gen. nov., a new genus of the order Actinomycetales. Int J Syst Bacteriol 44, 230-234.

Kroppenstedt, R. M. (1985). Fatty acid and menaquinone analysis of actinomycetes and related organisms. In Chemical Methods in Bacterial Systematics, pp. 173-199. Edited by M. Goodfellow \& D. E. Minnikin. London: Academic Press, Ltd.

Lechevalier, M. P. \& Lechevalier, H. A. (1970). Chemical composition as a criterion in the classification of aerobic actinomycetes. Int J Syst Bacteriol 20, 435-443.

Lechevalier, M. P., DeBièvre, C. \& Lechevalier, H. A. (1977). Chemotaxonomy of aerobic actinomycetes: phospholipid composition. Biochem Syst Ecol 5, 249-260.

Lee, S. D. (2006). Actinocorallia cavernae sp. nov., isolated from a natural cave in Jeju, Korea. Int J Syst Evol Microbiol 56, 1085-1088.

Rayner, R. W. (1970). A Mycological Colour Chart: Commonwealth Mycological Institute, Kew, Surrey \& British Mycological Society.

Saitou, N. \& Nei, M. (1987). The neighbor-joining method: a new method for reconstructing phylogenetic trees. Mol Biol Evol 4, 406-425.

Seino, A., Arai, M., Enokida, R., Okazaki, T. \& Furuichi, A. (1985). Identification Manual of Actinomycetes. Tokyo: The Society for Actinomycetes Japan.

Shirling, E. B. \& Gottlieb, D. (1966). Methods for characterization of Streptomyces species. Int J Syst Bacteriol 16, 313-340.

Tamura, T. \& Hatano, K. (2001). Phylogenetic analysis of the genus Actinoplanes and transfer of Actinoplanes minutisporangius Ruan et al. 
1986 and 'Actinoplanes aurantiacus' to Cryptosporangium minutisporangium comb. nov. and Cryptosporangium aurantiacum sp. nov. Int $J$ Syst Evol Microbiol 51, 2119-2125.

Tamura, T., Nakagaito, Y., Nishii, T., Hasegawa, T., Stackebrandt, E. \& Yokota, A. (1994). A new genus of the order Actinomycetales, Couchioplanes gen. nov., with descriptions of Couchioplanes caeruleus (Horan and Brodsky 1986) comb. nov. and Couchioplanes caeruleus subsp. azureus subsp. nov. Int J Syst Bacteriol 44, 193-203.

Tamura, T., Suzuki, S. \& Hatano, K. (2000). Acrocarpospora gen. nov., a new genus of the order Actinomycetales. Int J Syst Evol Microbiol 50, $1163-1171$.
Trujillo, M. E. \& Goodfellow, M. (2003). Numerical phenetic classification of clinically significant aerobic sporoactinomycetes and related organisms. Antonie van Leeuwenhoek 84, 39-68.

Yokota, A., Tamura, T., Hasegawa, T. \& Huang, L. H. (1993). Catenuloplanes japonicus gen. nov., sp. nov., nom. rev., a new genus of the order Actinomycetales. Int J Syst Bacteriol 43, 805-812.

Zhang, Z., Kudo, T., Nakajima, Y. \& Wang, Y. (2001). Clarification of the relationship between the members of the family Thermomonosporaceae on the basis of 16S rRNA gene, 16S-23S rRNA internal transcribed spacer and 23S rRNA gene sequences and chemotaxonomic analyses. Int J Syst Evol Microbiol 51, 373-383. 